\title{
معتقدات معلمات الرياضيات في مدينة الرياض حول التقويم التكويني
}

\section{عائشة محمد خليفة}

أستاذ مساعد بقسم المناهج وطرق التدريس - كلية التربية - جامعة تبوك

albalawi.aishah@gmail.com

تركز هذه الدراسـة على استكثاف معتقدات معلمات الرياضيات حول التقويم التكويني، وأبرز الممارسـات التقويمية التي

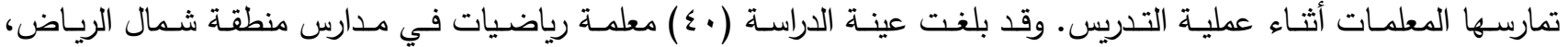
واستخدمت الباحثة المنهج الوصفي المسحي لتحقيق الهدف من الدراسة. وقد أظهرت النتائج أن هنالك تجانسًا في موافقة جميع أفراد العينة على الغرض من استخدام التقويم التكويني وهو إحاطة التلاميذ بمستواهم حيث حققت هذه العبارة أعلى متوسط حسابي، وفيما يتعلق بالاستراتيجيات التقويمية المتبعة أثناء التدريس فقد حقتت عبارة " أهتم بالملاحظة الصفية لتلميذاتي" أعلى متوسط حسابي. وأشـارت عينـة الدراسـة إلى أن عدم كفاية الحصة الدراسية، وكثافة أعداد التلميذات في الفصل الواحد يحد من ممارسـة المعلمات لاستراتيجيات التقويم التكويني. وفي ضوء تلك النتائج خلصت الدراسة إلى عدد من التوصيات.

الكلمات المفتاحية: التقويم، التقويم البنائي، التغذية الراجعة، التحصيل الأكاديمي.

\section{(c) (1)}

(المقدمة:

تعد العملية التعليمية من أهم العمليات الحيوية التي تؤثر في تقدم المجتمع وتطوره، وتثمل العملية التعليمية سلسلة من العناصر المترابطة والتي لا يمكن عزلها عن بعضها البعض، ابتداءً بتخطيط التدريس وانتهاءً بتقويم التدريس. فعناصر المنظومة

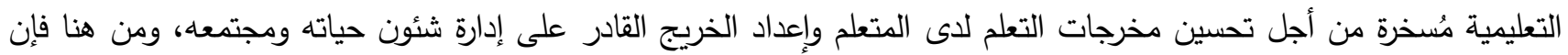

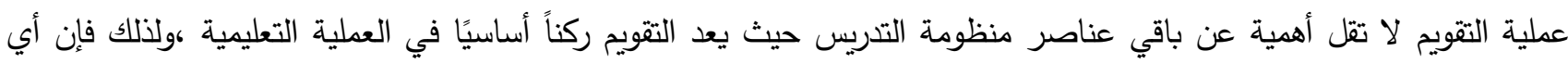
محاولة لإصلاح التعليم لا بد أن تشمل تطويرًا لفلسفة التقويم وطرائقه، ولقد برز في الآونة الأخيرة اهتمام بالتقويم نتيجةً للتطور في فئي

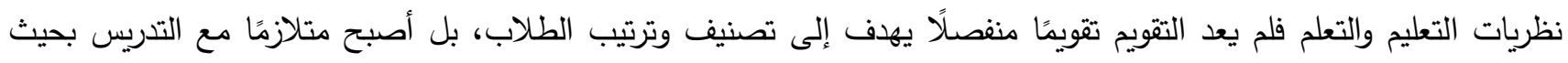

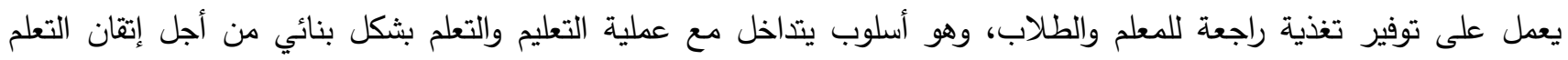

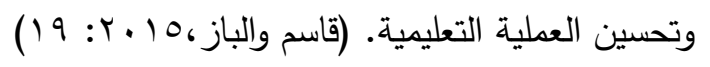

وتشمل عملية تقويم المنهاج التعليمي عدة مجالات، منها تقويم عناصر المنهاج المتمثلة في (الأهداف، المحتوى، الأنشطة، التقويم). وتقويم عمليات المنهاج والمتمثلة في (التصميم، التتفيذ، التطوير، تقويم التقويم). كما تشمل تقويم عمليات التعليم والتعلم (طرائق التدريس، أساليب التقويم، استخدام الأنشطة، استخدام الوسائل التعليمية). بالإضافة إلى تقويم العمليات المؤثرة في المنهاج

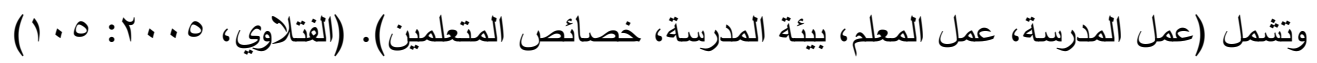


ويعد تقويم الطلبة مرحلة حساسة ومهمة من مراحل العملية التعليمية وأكثرها ارتباطًا بالتطوير التربوي الذي يسعى إليه الكثير

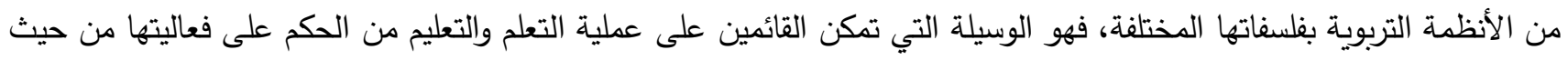
النتائج المطلوبة ومدى ملاءمتها لمستويات وقدرات الطلبة العقلية والنفسية.

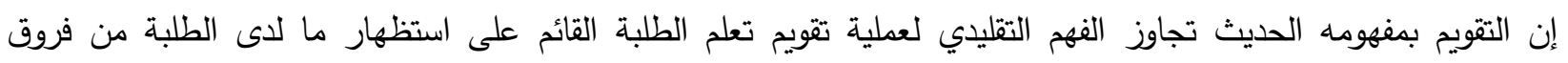

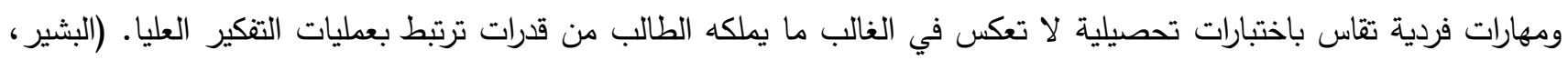

$(r \leqslant \leqslant: r \cdot 10$

\section{أهمية التقويم في التعليم:}

تؤكد النظرة الحديثة للتعلم على الترابط الكبير بين التقويم وعملية التعليم حيث إنهما جزء واحد من عملية متكاملة ويسيران معاً بشكل متلازم، فالتقويم يؤثر بصورة مباشرة وغير مباشرة على التعليم، فهو يؤثر بصورة مباشرة لأنها يوفر التغذية الراجعة الضرورية

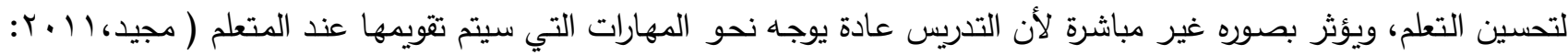
$(19-11$ والتقويم يزود التعليم ببيانات تكوينية وبيانات ختامية، فالبيانات الختامية تهدف إلى تحديد الدرجات وترتيب مستوى الطلاب عند

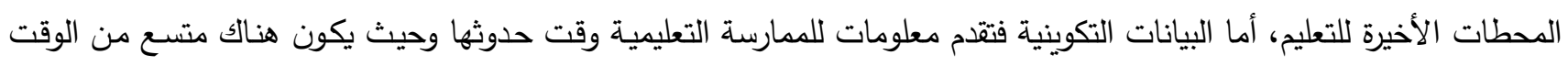

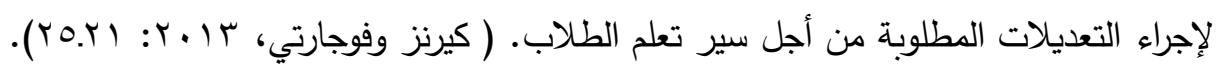

مفهوم التقويم التكويني والغزض من استخدامه في العملية التعليمية:

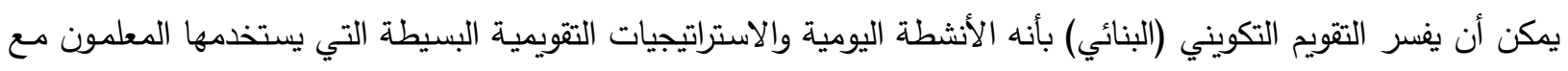
طلابهم و يتم دمجها طوال فترة تعليم الدرس بحيث تقدم معلومات تستخدم كتغذية راجعة تخبر المعلم عن فاعلية التعليم كما تخبر

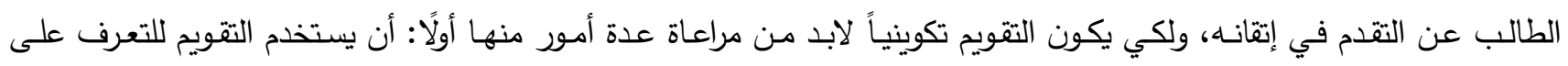

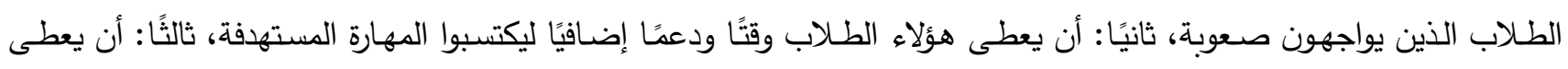

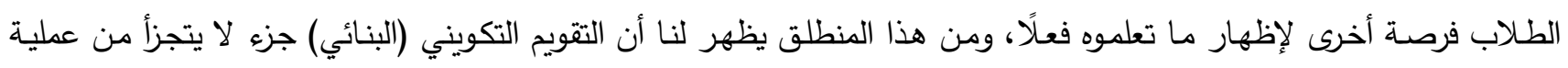

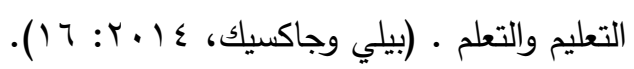
ويشير "البرصـان" إلى وجود عدة مسميات للتقويم البنائي في أدبيات التربية، منها التقويم التكويني والتقويم البنائي والتقويم

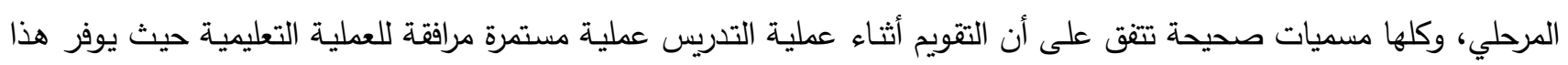

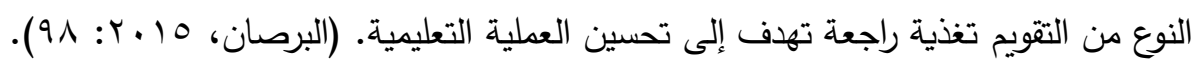
كما عرف المؤتمر الدولي للأبحاث والابتكار والسياسة (CERI, 2008) التقويم التكويني بأنه جزء من العملية التعليمية التي تهدف إلى توفير المعلومات اللازمة بشكل مستمر وهو يشمل تقويم المعلمين والطلاب في الوقت نفسه بهدف تكييف عملية التعليم

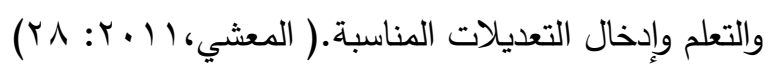
ويهدف هذا النوع من التقويم إلى تثخيص نواحي القوة والضعف لدى الطالب مما يساهم في توفير التغذية الراجعة المناسبة

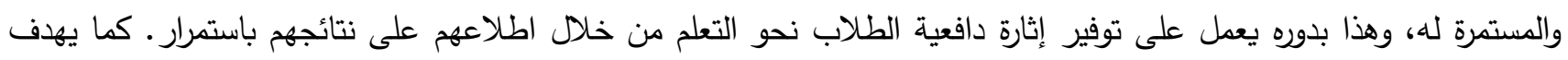

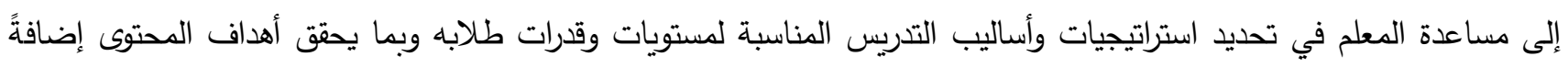

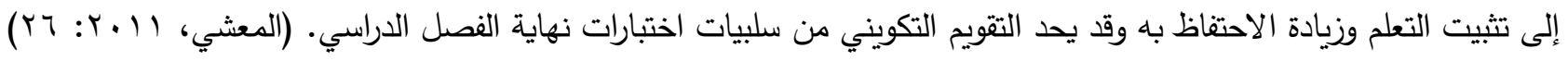


وذكر الكندري (7 1 • Y: 101) أنه يمكن استخدام عدد من الأساليب والأدوات للتأكد من تعلم التلاميذ للمادة العلمية، فقد يطرح المعلم أسئلة شفهية أثناء الحصة الدراسية، وقد يجري اختبارًا قصيرًا وقد يطلب من التلاميذ حل عدد من التمارين ويمكن أن يستخدم التهائ قوائم التقرير في الاروس العملية، وقد يصمم المعلم نوعًا من الاختبارات التشخيصية لتغطية وحدة من وحدات المنهاج الذي يقوم بتدريسه. ويرى تيرني وتشارلند (Tierney and Charland, 2007) أن التقويم التكويني يجب أن يتكون من العناصر الرئيسة التالية:

ا ـ . تحديد الأهداف التعليمية المراد تحقيقها بوضوح.

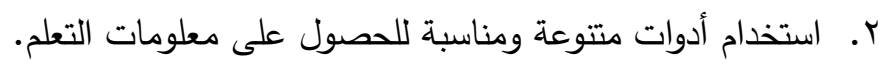
r. تسجيل ردود الفعل بهدف تحسين عملية التعليم والتعلم.

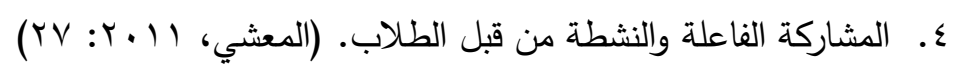

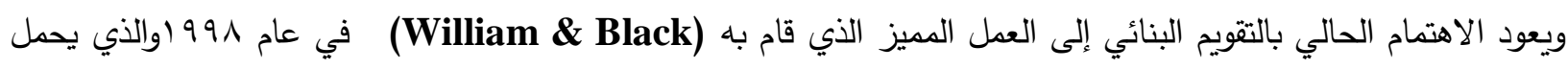
عنوان "داخل الصندوق الأسود" وهو تحليل متعمق للأبحاث حول التقويم وتوصل إلى نتيجتين هما:

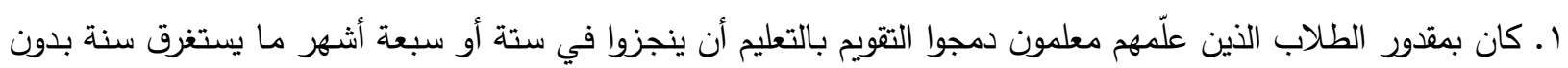
تلك العملية. r إن هذه التحسينات تبدوا متسقة عبر البلدان وعبر المستويات العمرية وعبر المواد الدراسية. وقد أثارت هاتان النتيجتان الكثير من الباحثين في المجال التربوي مدا دفعهم إلى التقصي عن طبيعة استراتيجيات التقويم التي

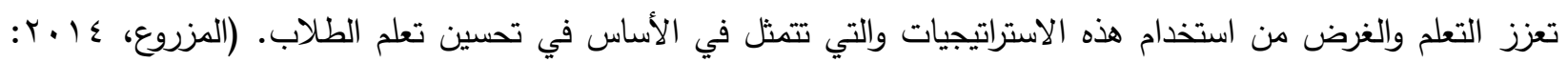

إضافة إلى ما أكدته العديد من الأبحاث العربية والعالمية من ضرورة تعزيز ممارسات التقويم التكويني (البنائي) في الفصول

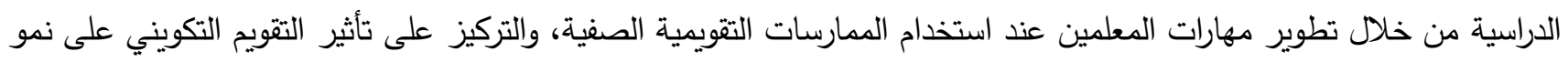
التعلم، والبحث في العوائق التي تحول دون استخدامه في الفصول الدراسية، وأوصت المؤتمرات العربية بوضع إطار مرجعي خليجي تلئي

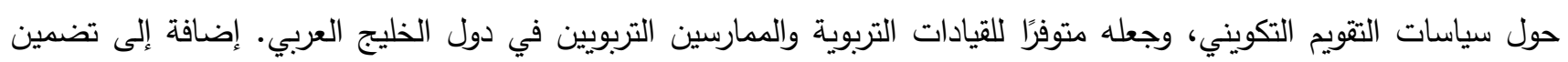

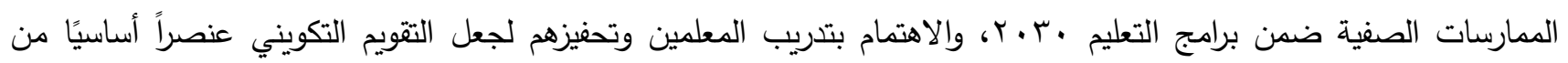

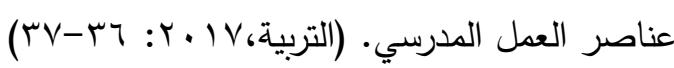
وقد تتاول الأدب التربوي العديد من الدراسات التي ناقشت الممارسات التقويمية التي يستخدمها المعلم اثناء تتفيذ عملية التدريس وذلك لما لتلك الممارسات من أهمية كبيرة في تحسين عملية التعليم. ومن هذه الدراسات دراسة نوعية أجرتها اوستن هارد قامت فيها باستكثاف كيفية إدارة المشاركين لعملية التقويم التكويني وذلك من خلال الملاحظة،

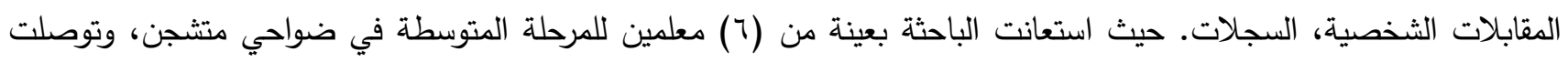

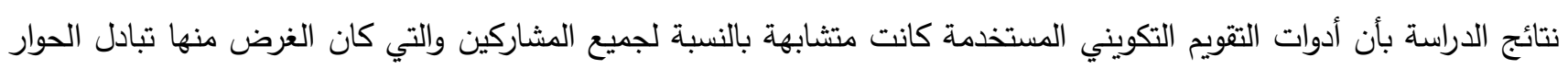

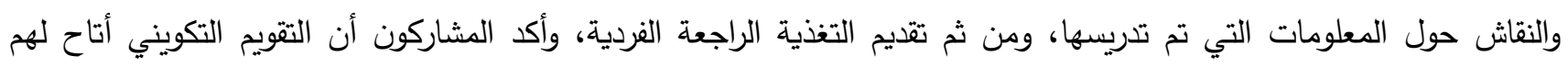
التعديل على تخطيط التدريس كما أشار المشاركون أن الوقت كان عاملاً مهماً لتحديد ملاءمة وسهولة استخدام استراتيجية التقويم التكويني. وبمراجعة النتائج النهائية نجد أن بعض المشاركين هم فعلًا ممن استطاع إيجاد الطريقة الأمثل لتحقيق الهدف والغرض ملفي من التقويم التكويني بصورة صحيحة. 
وسعت دراسة البرصان (10 ( + إلى تحليل الممارسات التقويمية التكوينية المتعلقة بالواجبات والممارسات الصفية غير

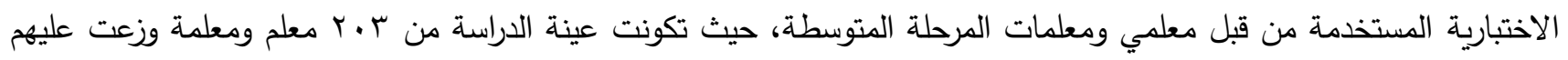
استبانة لقياس ممارسات التقويم التكويني والختامي، أشارت النتائج إلى أن من أكثر الممارسات التقويمية استعمالًا؛ اكتفاء المعلمين بالأسئلة الموجودة في الكتاب المدرسي ، أما من ناحية الأقل شيوعًا فكانت مشاركة الطالب في تحديد وتصحيح الواجب البيتي ذاتئي البياً أو جماعيًا الأمر الذي يفقد الطالب مهارة التقويم الذاتي، وأوصت الدراسة بضرورة تدريب المعلمين على أساليب التقويم التكويني. وقامت ماري جيوجيقان (Geoghegan, 2014) بعمل مقابلة شخصية متعمقة وتدوين ملاحظاتها خلال زيارتها للمشاركين

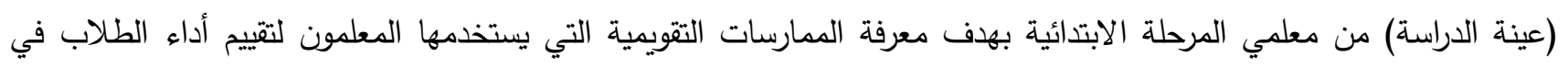

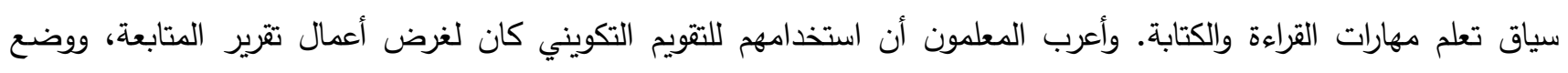
الطلاب في مجموعة القدرات، المساعدة في إعادة التدريس. وقد أثرت هذه الدراسة في فهم المعلمين لحقيقة التقويم التكويني وأنه يجب أن يستخدم كدليل لتحسين التدريس في الصف ومساعدة الطلاب في اكتشاف أهداف التعلم.

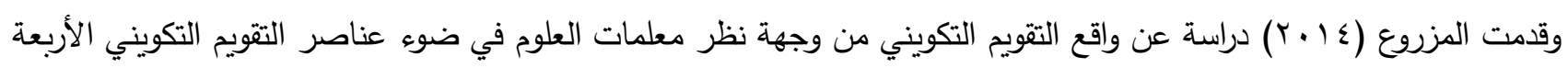

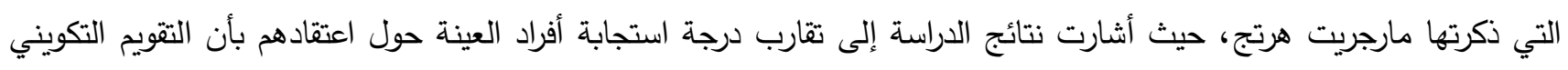

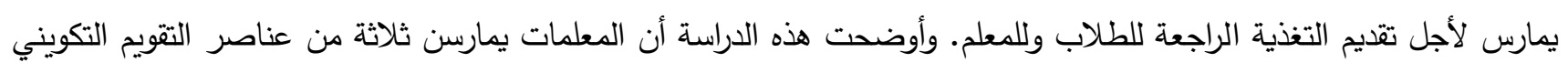

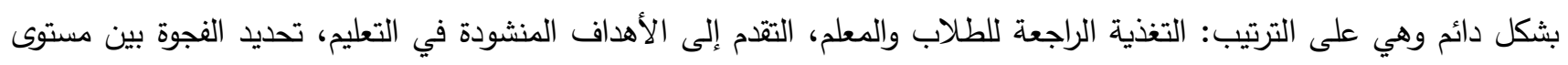
التعليم الحالي والأهداف التعليمية المرغوب فئها. وتؤكد هذه الدراسة بأن هناك حاجة لتتمية وعي المعلم بالتقويم التكويني وكيفية

تطبيقه.

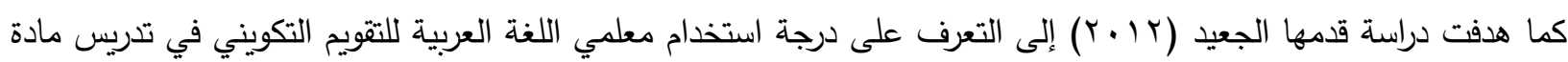

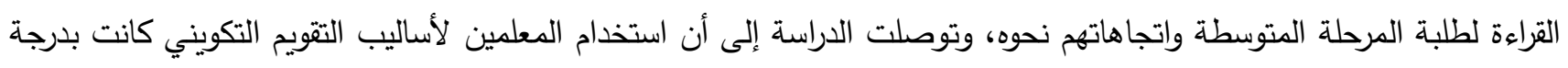

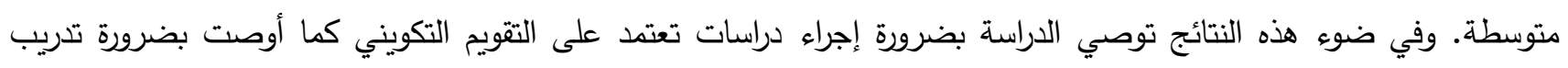

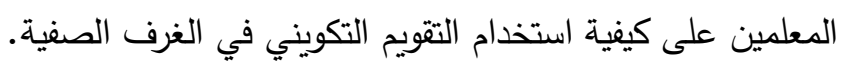

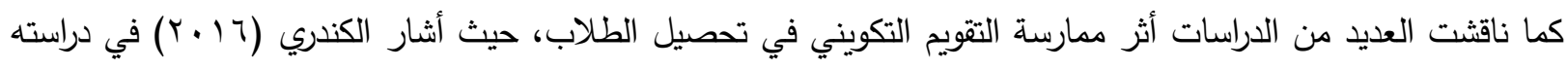

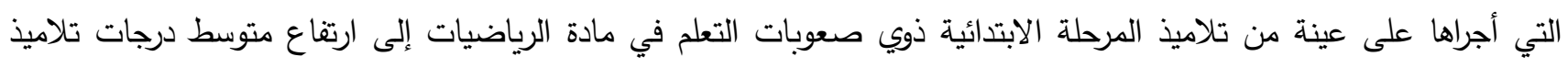
المجموعة التجريبية التي درست باستخدام برنامج التقويم التكويني مقارنة بدرجات المجموعة الضابطة التي درست بالطريقة دالتئة التقليدية.

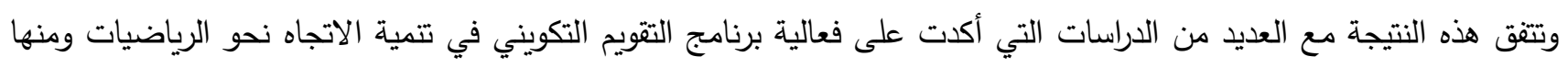

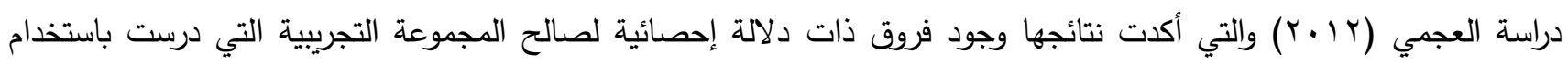
التقويم التكويني مما يدل على تحسن في التحصيل الدراسي في مهارات مادة اللغة العربية عند طلاب الصف السفات السابع.

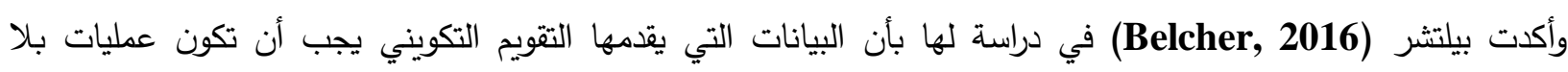
درجات توفر للطلاب والمعلمين تغذية راجعة ذات صلة بسير عملية التعليم، كما توفر استراتيجيات بديلة للمساعدة في تصحيح

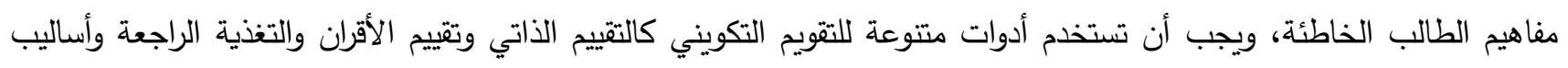

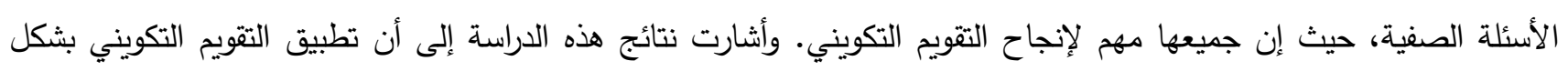
فعال أدى إلى تحسن ملحوظ في إنجاز طلاب الصف الثامن في مادة الرياضيات. ونختم في هذا السياق بدراسـة ديبياسي (DiBiase, 2014) والتي أبرزت منفعة التقويم التكويني كعملية يستخرج منها المعلم معلومات عن مستوى تقدم الطالب واستخدام هذه البيانات للإخبار بأن تدريسهم قد أبدى نتائج واعدة في إنجاز الطلاب. وأضافت الترات 
ديبياسي أن توظيف التقويم التكويني بشكل فعال وبوقت مبكر عند تتفيذ التدريس ينتج عنه تحسن كبير في إنجاز الطلاب، ولن يتم ذلك إلا بالتطوير المهني الثامل للمعلمين والذي سوف يساهم في إحداث أثر كبير في ممارساتهم التعليمية".

مشكلة الاراسة:

تحددت مشكلة الدراسة في الإجابة عن التساؤلات التالية:

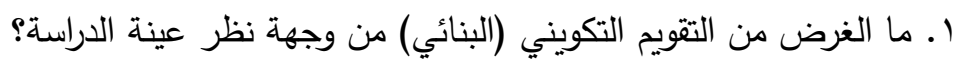

r. ما استراتيجيات التقويم التكويني (البنائي) التي تمارسها عينة الدراسة أثناء تتفيذ عملية التعليخ؟

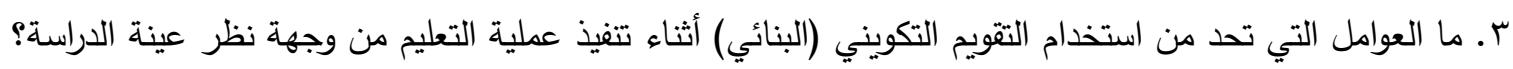

الهزف من الاراسة:

1 ـ تحديد درجة وعي المعلمات حول الغرض من استخدام التقويم التكويني (البنائي)؟

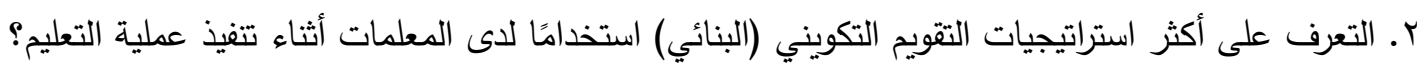

r. تحديد العوائق التي تحد من استخدام التقويم التكويني (البنائي) أثناء تتفيذ عملية التعليم؟

\section{أهمية الاراسةة:}

تظهر أهمية البحث جلية كونه يناقش عنصرًا من عناصر العملية التعليمية وأحد التوجهات الحديثة في مجال التقويم التربوي، كما يمكن أن يسهم هذا البحث في إعطاء صانعي القرار في المؤسسات التربوية تصورًا ورؤية واضحة حول أساليب واستراتيجيات التقويم المتبعة في المؤسسات التربوية، وخاصة استراتيجيات التقويم التكويني الممارسة أثناء تتفيذ عملية التدريس، وبالتالي تمكنهم من رسم خطط واضحة وفعالة في إرشاد المعلمين إلى طرائق وأساليب التقويم الحديثة وفق التوجهات الحديثة في عملية تقويم المتعلم.

\section{حدود الدراسة:}

تقتصر هذه الدراسة على استكثاف ومعرفة معتقدات معلمات الرياضيات حول التقويم التكويني، وقد طبقت هذه الدراسة على عينة

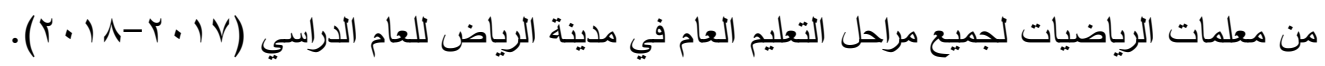

مصطلحات الدراسة:

مفهوم التقويم في النظام التربوي: العملية التي تستخدم فيها نتائج عملية القياس الكمي والكيفي في إصدار حكم على جانب معين من جوانب شخصية المتعلم، واتخاذ قرارات بغرض تطوير وتحسين نتاجات التعلم. (الخليفة وهاشم، 0 ( • ب: 1 1 ). التقويم التكويني(البنائي): مراقبة تقدم تعلم الطلاب أثناء التدريس بغرض توفير واندين التغذية الراجعة للطلاب وتزويد المعلم

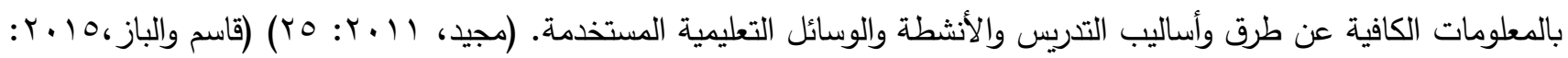

المعتقدات: إطار فكري تشكل بفعل الخبرة الشخصية والمعرفة المهنية، وتتداخل فيه مكونات معرفية وانفعالية وتقويمية، يستتد إليه المعلم في التخطيط واتخاذ القرارات وتحديد المهام المتعلقة بالمواقف الصفية ويستدل عليه من أقوال المعلم وسلوكه.

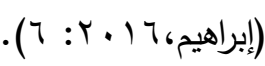


في ضوء طبيعة الدراسة والأهداف التي تسعى إلى تحقيقها للتعرف على معتقدات معلمات الرياضيات حول التقويم

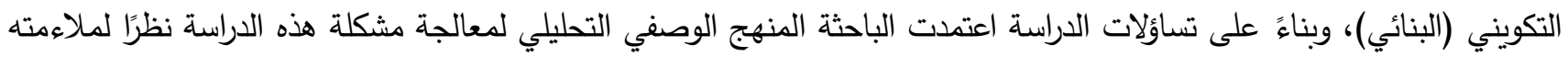

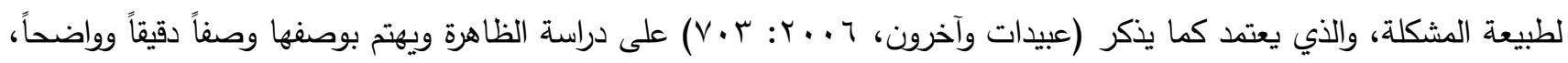

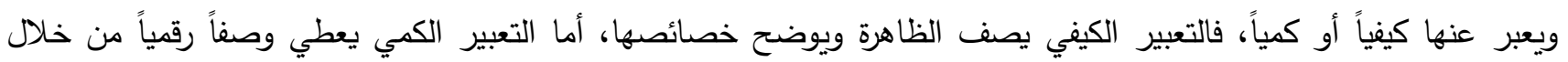
توضيح مقدار هذه الظاهرة أو حجمها ودرجات ارتباطها مع الظواهر المختلفة.

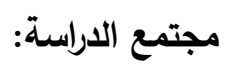
يتمثل مجتمع الدراسة الحالية من جميع معلمات الرياضيات في مختلف مراحل التعليم العام، الابتدائي والمتوسط والثانوي

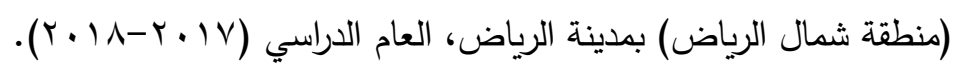

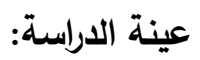
تكونت عينة الدراسة من (•؛) معلمة من منسوبات التعليم العام بدينة الرياض.

\section{وصف خصائص عينة الدراسة:}

جدول ( ) : توزيع مفردات عينة الدراسة وفقًا لمتغيرات المرحلة التدريسية، سنوات الخبرة، والدروات التدريبية

\begin{tabular}{|c|c|c|c|}
\hline \multicolumn{4}{|c|}{ جدول خصائص عينة الدراسة: المرحلة التدريسية، الدورات التدريبية، عدد سنوات الخبرة } \\
\hline 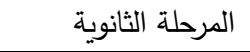 & 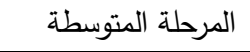 & 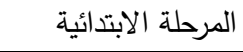 & 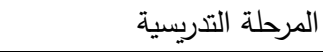 \\
\hline 1 & 17 & 11 & العدد \\
\hline$\% 10$ & $\% \varepsilon$ & $\% \leqslant 0$, & 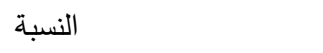 \\
\hline أكثر من ثلاث دورات & ثلاث دورات & أقل من ثلاث دورات & 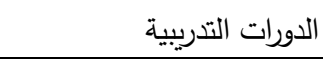 \\
\hline ir & 9 & 11 & العدد \\
\hline$\%$ \%r,o & $\% r r, 0$ & $\% \leq 0$ & النسبة \\
\hline أكثر من · ا سنوات & 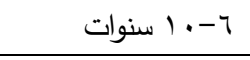 & 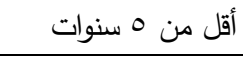 & 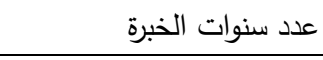 \\
\hline rr & ir & $\circ$ & العدد \\
\hline$\% \circ \vee, 0$ & $\% r \cdot, \cdot$ & $\% \backslash r, 0$ & النسبة \\
\hline
\end{tabular}

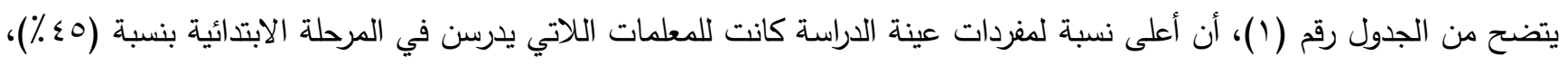

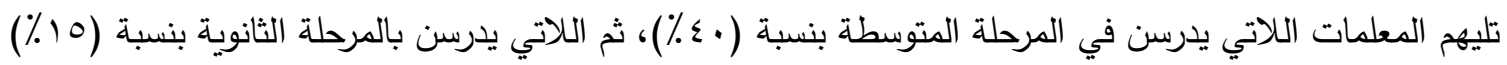

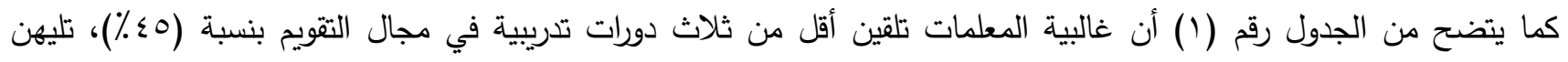

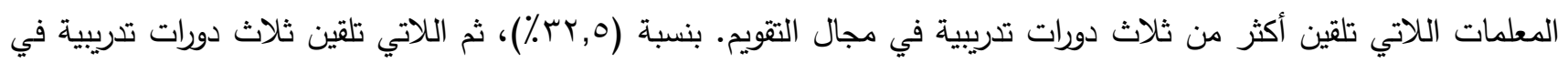

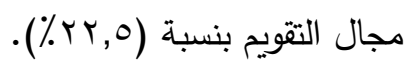


ويتبين من الجدول رقم (1) أن المعلمات محل الدراسة خبرتهن الوظيفية أكثر من · 1 سنوات بنسبة (ov,0\%) وهن غالبية مفردات

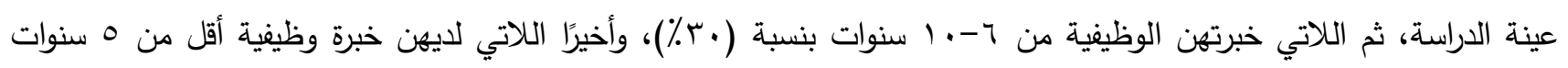

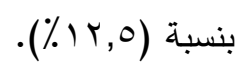

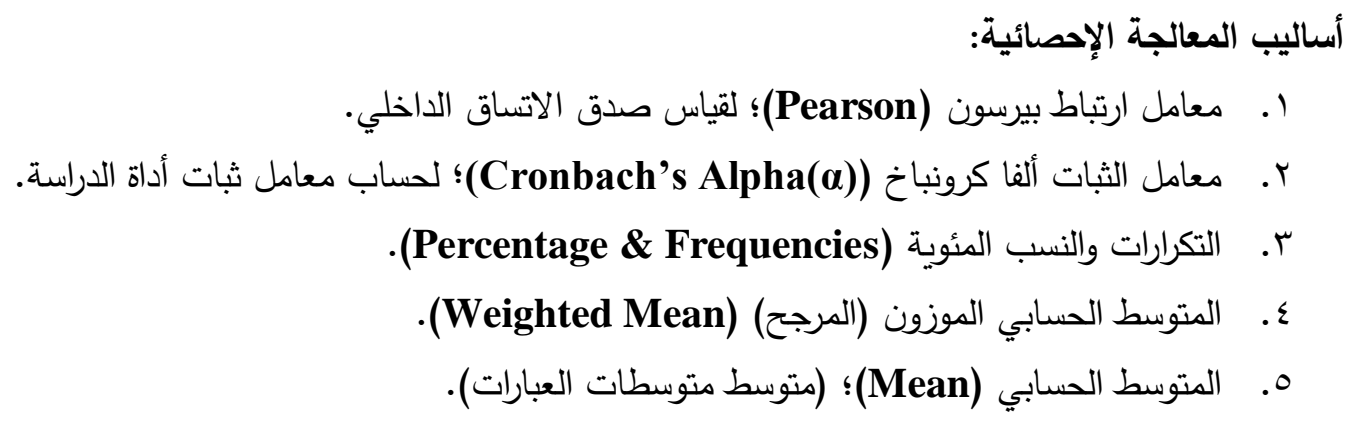

7. الانحراف المعياري (Standard Deviation).

أداة الدراسة:

استخدمت الاستبانة كأداة لجمع البيانات، بناءً على أهداف الدراسة وأسئلتها ومنهجها وطبيعة موضوعها، وبسبب تتوع مجتمع الدي

الدراسة، تعتبر الاستبانة الأداة الأفضل في جمع البيانات من عينة الدراسة.

وتم تصميم الاستبانة بعد مراجعة للإطار النظري والدراسات السابقة وتوصيات المؤتمرات، والندوات المحلية والعربية، وتكونت في صورتها النهائية من جزأين هما:

ا.البيانات الأولية: تتعلق بالمتغيرات المستقلة، والتي تتضمن المتغيرات ذات العلاقة بالبيانات الثخصية والوظيفية لعينة الدراسة،

وتثتمل على (المرحلة التدريسية، عدد الدورات التدريبية في مجال التقويم، الخبرة الوظيفية). r.فقرات الاستبانة: تثمل الاستبانة (r Y) فقرة تقيس معتقدات معلمات الرياضيات حول التقويم التكويني (البنائي).

صدق أداة الدراسة:

إن أحد الأسس العلمية لتقنين المقياس، توافر خاصية الصدق (Validity)، وللتحقق من صدق أداة الدراسة تم استخدام

طريقتين على النحو الآتي:

أ. الصدق الظاهري (External Validity) للأداة:

للتعرف على مدى صدق أداة الدراسة في قياس ما وضعت لقياسه تم عرضها على مجموعة من المحكمين والخبراء من ذوي الخبرة والاختصاص في الجامعات والذين بلغ عددهم أربعة محكمين.

ب.صدق الاتساق الداخلي: بعد التأكد من الصدق الظاهري لأداة الدراسة تم تطبيقها ميدانيًا ثم تم حساب معامل ارتباط بيرسون بين الدرجة لكل عبارة تتتمي لكل محور والدرجة الكلية لهذا المحور الذي تتتمي إليه، وأظهرت النتائج أن قيم معاملات الارتباط موجبة ودالة إحصائيًا عند مستوى الدلالة (1 ., • ) مما يشير إلى صدق الاتساق الداخلي. 
ثبات أداة الدراسة:

لقياس مدى ثبات أداة الدراسة تم استخدام (معادلة ألفا كرونباخ) (Cronbach's Alpha (a) للتأكد من ثبات أداة الدراسة،

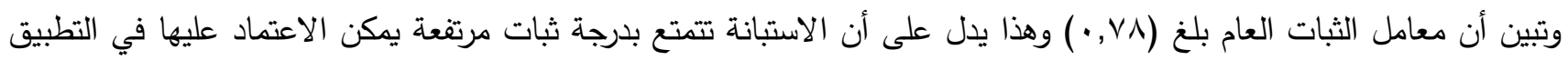
الميداني للدراسة.

إجراءات تطبيق أداة الدراسة:

طبقت أداة الدراسة بعد إتمام خطوات بنائها وتقنينها والتأكد من صدقها وثباتها؛ وإخراجها في صورتها النهائية، واستكمال

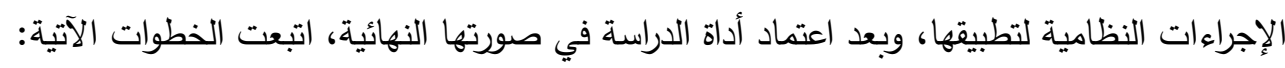

$$
\text { r. ا. توزيع الاستبانة على عينة البحث. }
$$

r. استغرقت عملية توزيع وجمع البيانات (• (7) يوماً تقريباً.

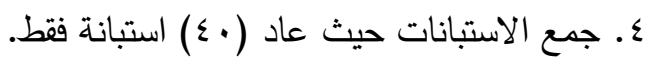

ه. تقريغ إجابات مفردات الدراسة وفق مقياس ليكرت الخماسي في قاعدة البيانات في برنامج الحزم الإحصائية للعلوم

الاجتماعية (SPSS)

7. استخراج النتائج وتحليلها ومناقشتها ووضع التوصيات والمقترحات.

النتائج:

تحليل بيانات السؤال الأول "ما الغرض من التقويم التكويني (البنائي) من وجهة نظر عينة الاراسة؟"

الجدول (ץ): التكرارات والنسب المئوية وإلمتوسطات الحسابية والانحرافات المعيارية لعبارات الهذف من استخدام المعلمة للتقويم البنائي

\begin{tabular}{|c|c|c|c|c|c|c|c|c|c|c|}
\hline \multirow[t]{2}{*}{ الترتيب } & \multirow{2}{*}{ الانحراف } & \multirow{2}{*}{ الحسابي } & \multicolumn{5}{|c|}{ درجة الموافقة } & التكرار & \multirow[t]{2}{*}{ العبارة } & \multirow{2}{*}{ العبارة } \\
\hline & & & لا أوافق & لا أوافق & محايد & أوافق & وأوافق & النسبة & & \\
\hline \multirow[t]{2}{*}{7} & \multirow[t]{2}{*}{ 1,Irr } & \multirow[t]{2}{*}{$r, v r$} & $r$ & r & 0 & $r$. & 9 & كs & \multirow{2}{*}{ أشخص نقاط القوة عند } & \multirow[t]{2}{*}{1} \\
\hline & & & $\mathrm{v}, \mathrm{O}$ & $\mathrm{v}, \mathrm{O}$ & $1 T, 0$ & $0 .$, & $Y Y, O$ & $\%$ & & \\
\hline \multirow[t]{2}{*}{ V } & \multirow[t]{2}{*}{$1, Y Y \varepsilon$} & \multirow[t]{2}{*}{$r, v}$. & $\varepsilon$ & $r$ & $\varepsilon$ & 19 & 1. & ك & \multirow{2}{*}{ أشخص نقاط الضعف التلميذة } & \multirow[t]{2}{*}{ r } \\
\hline & & & $1 \cdot, 0$ & $\mathrm{v}, \mathrm{O}$ & $1 \cdot, \cdot$ & $\varepsilon \vee$, & ro,. & $\%$ & & \\
\hline \multirow[t]{2}{*}{$r$} & \multirow[t]{2}{*}{ •, $9 \Gamma \varepsilon$} & \multirow[t]{2}{*}{$\varepsilon, \cdots$} & 1 & $r$ & 0 & $r$. & IT & ك & \multirow{2}{*}{ أمنح التلميذة التغذية } & \multirow[t]{2}{*}{$r$} \\
\hline & & & $r, 0$ & $0, \cdot$ & $1 Y, 0$ & o., & $r_{\cdot}, \cdot$ & $\%$ & & \\
\hline \multirow[t]{2}{*}{$r$} & \multirow[t]{2}{*}{$\cdot, 9 \leq \varepsilon$} & \multirow[t]{2}{*}{$\varepsilon, \cdot V$} & 1 & $r$ & $\varepsilon$ & 19 & $1 \varepsilon$ & ك & \multirow{2}{*}{ ألتلميذة لعناصر الدرسة استجابة } & \multirow[t]{2}{*}{$\varepsilon$} \\
\hline & & & $r, 0$ & $0, \cdot$ & $1 \cdot, \cdot$ & $\begin{array}{c}\varepsilon V, \\
0\end{array}$ & ro,. & $\%$ & & \\
\hline
\end{tabular}
مرتبة تنازليا حسب المتوسط الحسابي والحرات 


\begin{tabular}{|c|c|c|c|c|c|c|c|c|c|c|}
\hline \multirow[t]{2}{*}{ الترتيب } & \multirow{2}{*}{ الانحراف } & \multirow{2}{*}{ الحسابي } & \multicolumn{5}{|c|}{ درجة الموافقة } & التكرار & \multirow[t]{2}{*}{ العبارة } & \multirow{2}{*}{ رقب } \\
\hline & & & لا أوافق & لا أوافق & محايد & أوافق & وأوافق & النسبة & & \\
\hline \multirow[t]{2}{*}{9} & \multirow[t]{2}{*}{$1, .01$} & \multirow[t]{2}{*}{$r, 70$} & $r$ & $r$ & 1. & IV & $\wedge$ & ك & \multirow{2}{*}{ 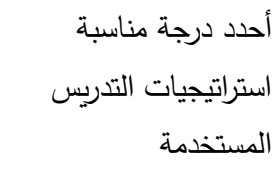 } & \multirow[t]{2}{*}{0} \\
\hline & & & $0, \cdot$ & $v, o$ & ro,. & $\begin{array}{c}\varepsilon r, \\
0\end{array}$ & $r_{\cdot, \cdot}$ & $\%$ & & \\
\hline \multirow[t]{2}{*}{1} & \multirow[t]{2}{*}{$\cdot, 109$} & \multirow[t]{2}{*}{$\varepsilon, \cdot V$} & r & - & 1 & $r V$ & 1. & كs & \multirow{2}{*}{ الإحاطة بمستوى أدائها } & \multirow[t]{2}{*}{7} \\
\hline & & & $0, .9$ & - & $r, 0$ & $\begin{array}{c}T V, \\
0\end{array}$ & ro,. & $\%$ & & \\
\hline \multirow[t]{2}{*}{$\wedge$} & \multirow[t]{2}{*}{ 1,17 } & \multirow[t]{2}{*}{$r, \uparrow \Lambda$} & r & $\varepsilon$ & 0 & 19 & 9 & ك & \multirow{2}{*}{ أقيم أدائي ذاتياً } & \multirow[t]{2}{*}{ v } \\
\hline & & & $v, 0$ & $1 \cdot, \cdot$ & $1 r, 0$ & $\begin{array}{l}\varepsilon v, \\
0\end{array}$ & $r r, O$ & $\%$ & & \\
\hline \multirow[t]{2}{*}{1.} & \multirow[t]{2}{*}{$1, \cdot \Delta r$} & \multirow[t]{2}{*}{$r, \varepsilon r$} & $r$ & 0 & $\wedge$ & $r$. & $\varepsilon$ & ك5 & \multirow{2}{*}{ أعتامد عليه في التقويم } & \multirow[t]{2}{*}{$\wedge$} \\
\hline & & & $r, 0$ & $1, T, 0$ & $r \cdot, \cdot$ & .0 & $1 \cdot, \cdot$ & $\%$ & & \\
\hline \multirow[t]{2}{*}{0} & \multirow[t]{2}{*}{ •, 994 } & \multirow[t]{2}{*}{$r, \wedge}$. & $r$ & r & 7 & rT & $\wedge$ & ك5 & \multirow{2}{*}{ خلاله دافية التلميذات من } & \multirow[t]{2}{*}{9} \\
\hline & & & $0, \cdot$ & $0, \cdot$ & $10,$. & -0, & $r_{\cdot, \cdot}$, & $\%$ & & \\
\hline \multirow[t]{2}{*}{$\varepsilon$} & \multirow[t]{2}{*}{$1, \cdot A r$} & \multirow[t]{2}{*}{ r,Ar } & $r$ & r & $r$ & r & 9 & ك & \multirow{2}{*}{ ألتعلم درجة تحقق أهداف } & \multirow[t]{2}{*}{1.} \\
\hline & & & $v, 0$ & $0,$. & $v, 0$ & $\begin{array}{c}\text { ov, } \\
0\end{array}$ & $r r, O$ & $\%$ & & \\
\hline & & r,A. & & & & & ط العام & & & \\
\hline
\end{tabular}

ويتبين من الجدول رقم (Y) السابق ما يلي:

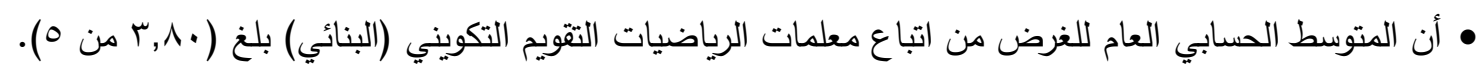
• أن هناك تجانساً في موافقة مفردات عينة الدراسة على الغرض من اتباع معلمات الرياضيات التقويم التكويني (البنائي)،

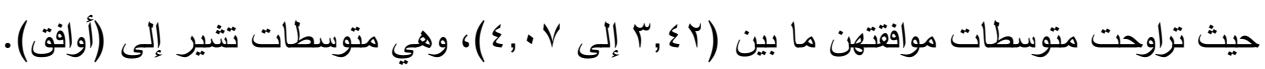

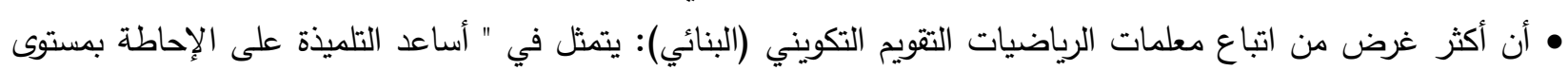

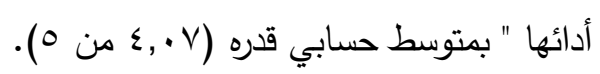
• أن أقل غرض من اتباع معلمات الرياضيات التقويم التكويني (البنائي)، يتمثل في " أعتمد عليه في التقويم الختامي للتلميذة "

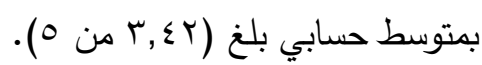

تحليل بيانات السؤال الثاني "ما استراتيجيات التقويم التكويني (البنائي) التي تمارسها عينة الدراسة أثناء تنفيذ عملية التعليم؟" 
جدول (ץ): التكرارات والنسب المئوية والمتوسطات الحسابية والانحرافات المعيارية لعبارات درجة استخدام المعلمة لاستراتيجيات التقويم

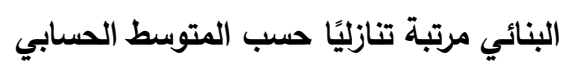

\begin{tabular}{|c|c|c|c|c|c|c|c|c|c|c|}
\hline \multirow[t]{2}{*}{ الترتيب } & \multirow{2}{*}{ المعياري } & \multirow{2}{*}{ الحسابي } & \multicolumn{5}{|c|}{ درجة الموافقة } & التكرار & \multirow[t]{2}{*}{ العبارة } & \multirow{2}{*}{ رقب } \\
\hline & & & لا لا وطلقاً & لا أوافق & محايد & أوافق & وأوبقة & النسبة & & \\
\hline \multirow[t]{2}{*}{0} & \multirow[t]{2}{*}{$\cdot, \wedge \vee \uparrow$} & \multirow[t]{2}{*}{$r, 00$} & 1 & - & rr & 1. & v & ك & \multirow{2}{*}{ 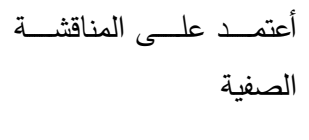 } & \multirow[t]{2}{*}{1} \\
\hline & & & $r, 0$ & - & $00,$. & ro, & IV,o & $\%$ & & \\
\hline \multirow[t]{2}{*}{$r$} & \multirow[t]{2}{*}{$\cdot, \wedge \leq \varepsilon$} & \multirow[t]{2}{*}{ r,یז } & - & 1 & 10 & $1 \varepsilon$ & 1. & ك & \multirow{2}{*}{ 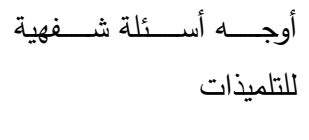 } & \multirow[t]{2}{*}{ r } \\
\hline & & & - & $r, 0$ & $r V, O$ & ro, & ro,. & $\%$ & & \\
\hline \multirow[t]{2}{*}{1} & \multirow[t]{2}{*}{$\cdot, \wedge \cdot 9$} & \multirow[t]{2}{*}{$\varepsilon, r_{O}$} & - & - & 9 & ir & 19 & ك & \multirow{2}{*}{ 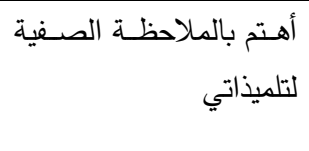 } & \multirow[t]{2}{*}{$r$} \\
\hline & & & - & - & Tr,O & $r \cdot$, & $\varepsilon \gamma, 0$ & $\%$ & & \\
\hline \multirow[t]{2}{*}{$\varepsilon$} & \multirow[t]{2}{*}{., 9 r. } & \multirow[t]{2}{*}{$r, v v$} & - & $r$ & ir & $1 \varepsilon$ & 1. & ك & \multirow{2}{*}{ 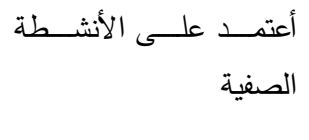 } & \multirow[t]{2}{*}{$\varepsilon$} \\
\hline & & & - & $v, 0$ & Tr,O & ro, & ro,. & $\%$ & & \\
\hline \multirow[t]{2}{*}{7} & \multirow[t]{2}{*}{$1, .09$} & \multirow[t]{2}{*}{$r, \varepsilon r$} & 1 & 7 & 17 & 9 & $\wedge$ & ك & \multirow{2}{*}{ 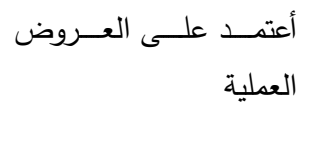 } & \multirow[t]{2}{*}{0} \\
\hline & & & $r, 0$ & 10, & $\{\cdot, 0$ & rr, & $r_{\cdot, \cdot}$ & $\%$ & & \\
\hline \multirow[t]{2}{*}{ r } & \multirow[t]{2}{*}{$\cdot, 9 Y \wedge$} & \multirow[t]{2}{*}{$r, q}$. & - & $r$ & ir & Ir & ir & ك & \multirow{2}{*}{ قصيرة أجري اختبـارات تحريريــة } & 7 \\
\hline & & & - & $0,$. & rT,O & $r \cdot$, & rr,o & $\%$ & & \\
\hline v & $1, \ldots$ & T,YY & r & 7 & iv & 11 & $\varepsilon$ & ك & أحــرص علـــى تقـــويم & v \\
\hline & & & $0, \cdot$ & $10,$. & $\{r, 0$ & $\begin{array}{l}\text { TV, } \\
0\end{array}$ & $1, \cdot$, & $\%$ & البعض التلميــات أداء بعضــــن & \\
\hline & & $r, v)$ & & & & & المتوسط & & & \\
\hline
\end{tabular}

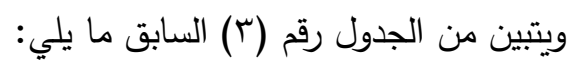
• أن المتوسط الحسابي العام لاستراتيجيات التقويم التكويني (البنائي) التي تمارسها معلمات الرياضيات أثناء تتفيذ عملية التعليم

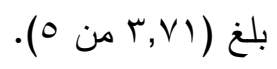
• أن هناك تبايناً في موافقة مفردات عينة الدراسة على استراتيجيات التقويم التكويني (البنائي) التي تمارسها معلمات الرياضيات

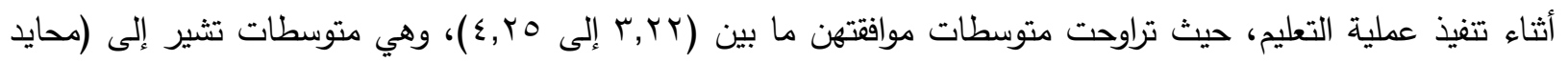
وأوافق وأوافق بشدة). • أن أقل استراتيجيات التقويم التكويني (البنائي) التي تمارسها معلمات الرياضيات أثناء تتفيذ عملية التعليم، تتمثل في "أحرص

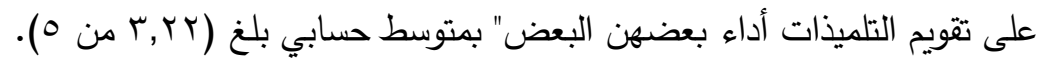


• أن أكثر استراتيجيات التقويم التكويني (البنائي) التي تمارسها معلمات الرياضيات أثثاء تنفيذ عملية التعليم: تتمثل في " أهتم بالملاحظة الصفية لتلميذاتي " بمتوسط حسابي قدره (0 ب, ع من ه). تحليل بيانات السؤال الثالث "ما العوامل التي تحد من استخدام التقويم التكويني (البنائي) أثناء تنفيذ عملية التعليم من وجهة نظر عينة الدراسة؟ باتهات جدول ( ) : التكرارات والنسب المئوية والمتوسطات الحسابية والانحرافات المعيارية لعبارات العوامل التي تحد من استخدام المعلمة للتقويم البنائي مرتبة تنازليًا حسب المتوسط الحسابي

\begin{tabular}{|c|c|c|c|c|c|c|c|c|c|c|}
\hline \multirow[t]{2}{*}{ الترتيب } & \multirow{2}{*}{ الانحراف } & \multirow{2}{*}{ المتوسط } & \multicolumn{5}{|c|}{ درجة الموافقة } & التكرار & \multirow[t]{2}{*}{ العبارة } & \multirow{2}{*}{ رقم } \\
\hline & & & لا مطلقاً & لا أوافق & محايد & أوافق & وأوافق & النسبة & & \\
\hline \multirow[t]{2}{*}{ r } & \multirow{2}{*}{$1, r \leq q$} & \multirow[t]{2}{*}{ T,YT } & iv & 9 & 0 & 7 & r & ك & \multirow{2}{*}{ 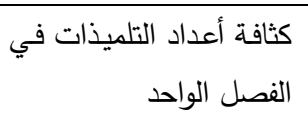 } & \multirow[t]{2}{*}{1} \\
\hline & & & $\varepsilon r, 0$ & 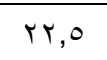 & $M, 0$ & 10 & $v, 0$ & $\%$ & & \\
\hline \multirow[t]{2}{*}{$\varepsilon$} & \multirow{2}{*}{$1,0 \leq \leq$} & \multirow[t]{2}{*}{ r, r } & 1. & $r$ & 0 & ir & 1. & S & \multirow{2}{*}{ 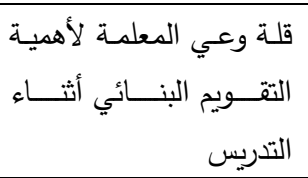 } & \multirow[t]{2}{*}{$r$} \\
\hline & & & ro,. & $v, 0$ & $M, 0$ & $r$. & ro & $\%$ & & \\
\hline \multirow[t]{2}{*}{ r } & \multirow[t]{2}{*}{$1, r \wedge 0$} & \multirow[t]{2}{*}{ r, } & 0 & V & 9 & $\wedge$ & 11 & 5 & \multirow{2}{*}{ التخفاض مستوى تحصيل } & \multirow[t]{2}{*}{$r$} \\
\hline & & & $M, 0$ & $1 V, 0$ & rr,O & $r$. & $r v, 0$ & $\%$ & & \\
\hline \multirow[t]{2}{*}{0} & \multirow[t]{2}{*}{1,170} & \multirow[t]{2}{*}{$r, \cdot r$} & $\varepsilon$ & $\wedge$ & iv & 0 & 7 & s & \multirow{2}{*}{ كثافــة محتــوى المــنهج } & \multirow[t]{2}{*}{$\varepsilon$} \\
\hline & & & $1, \cdot$. & $r \cdot, \cdot$ & $\varepsilon r, 0$ & $M, 0$ & 10 & $\%$ & & \\
\hline \multirow[t]{2}{*}{1} & \multirow[t]{2}{*}{$1, r V Y$} & \multirow[t]{2}{*}{ ס ז, ז } & $r$ & 9 & $\wedge$ & 11 & 9 & ك5 & \multirow{2}{*}{ للحصة كفايـة الوقت المتـاح } & \multirow[t]{2}{*}{0} \\
\hline & & & $v, 0$ & $r, 0$ & $r \cdot, \cdot$ & $r V, 0$ & $r, 0$ & $\%$ & & \\
\hline \multicolumn{2}{|c|}{ תזM, } & $r, \cdot r$ & \multicolumn{7}{|c|}{ المتوسط العام } & \\
\hline
\end{tabular}

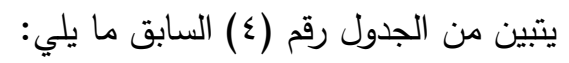
• أن المتوسط الحسابي العام للعوامل التي تحد من استخدام التقويم التكويني (البنائي) أثناء تتفيذ معلمات الرياضيات التدريس بلغ

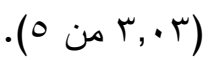
• أن هناك تجانساً في موافقة مفردات عينة الدراسة على العوامل التي تحد من استخدام التقويم التكويني (البنائي) أثناء تنفيذ

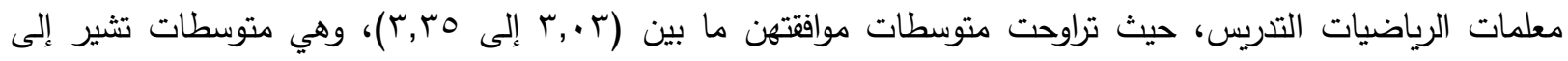
(محايد) معان) • أن أكثر العوامل التي تحد من استخدام التقويم التكويني (البنائي) أثناء تتفيذ معلمات الرياضيات التدريس: تتمثل في " عدم

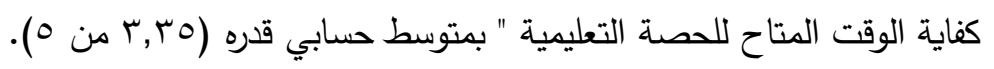
• أن أقل العوامل التي تحد من استخدام التقويم التكويني (البنائي) أثناء تتفيذ معلمات الرياضيات التيات التدريس، تتمثل في " كثافة محتوى المنهج الدراسي " بمتوسط حسابي بلغ (r. .ب من ه م). 


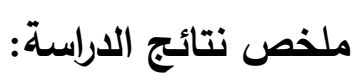

ملخص نتائج السؤال الأول: أظهرت النتائج ذات العلاقة بالسؤال الأول والذي نصه: "ما الغرض من التقويم التكويني (البنائي) من

وجهة نظر عينة الدراسة؟"

1. أن هناك تجانيًا في موافقة مغردات عينة الدراسة على الغرض من اتباع معلمات الترات الرياضيات التقويم التكويني (البنائي).

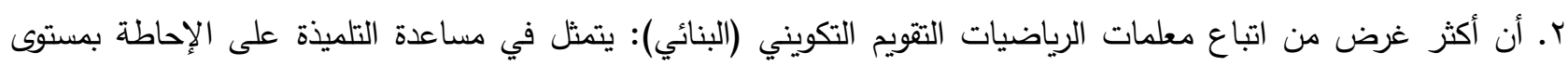

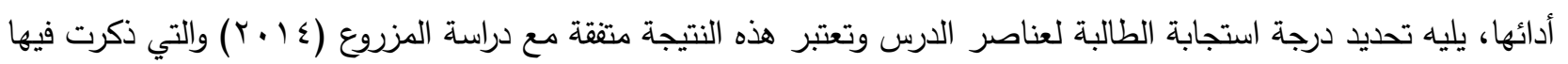

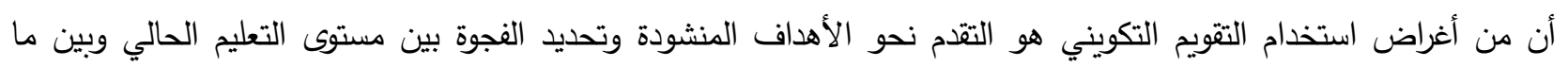

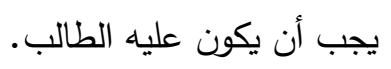
r. أن أقل غرض من اتباع معلمات الرياضيات التقويم التكويني (البنائي)، يتمثل في الاعتماد عليه في التقويم الختامي للتلميذة،

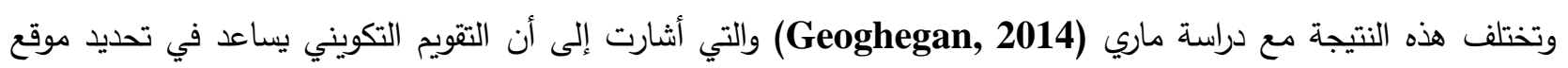
التلميذ في سجلات التقرير عند التقييم النهائي. ملخص نتائج السؤال الثاني: أظهرت النتائج ذات العلاقة بالسؤال الثاني والذي نصاه: "ما استراتيجيات التقويم التكويني (البنائي)

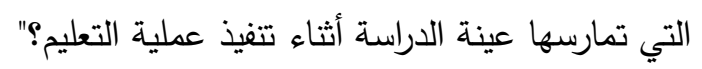
ا. أن معلمات الرياضيات موافقات على ممارسة استراتيجيات التقويم التكويني (البنائي) أثناء تتفيذ عملية التعليم.

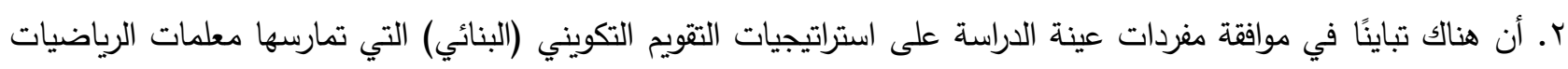
أثثاء تتفيذ عملية التعليم. ז. أن أكثر استراتيجيات التقويم التككيني (البنائي) التي تمارسها معلمات الرياضيات أثناء تتفيذ عملية التعليم: تتمثل في الاهتمام بالملاحظة الصفية للتلميذات. ع. أن أقل استراتيجيات التقويم التكويني (البنائي) التي تمارسها معلمات الرياضيات أثناء تتفيذ عملية التعليم، تتمثل في الحرص

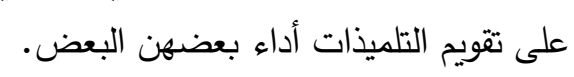

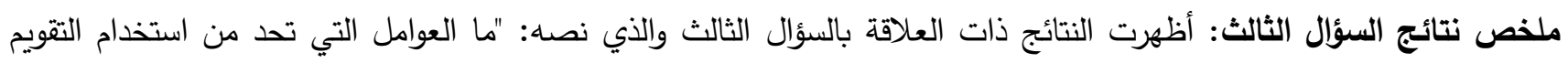

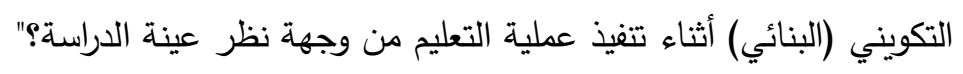

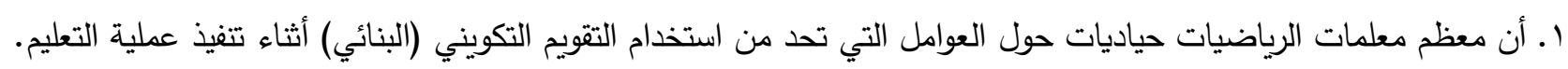

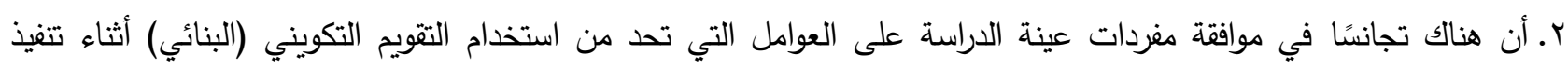

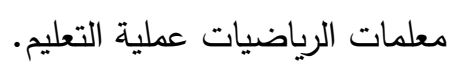
r. أن أكثر العوامل التي تحد من استخدام التقويم التكويني (البنائي) أثناء تتفيذ معلمات الرياضيات عملية التعليم: تتمثل في عدم كفاية الوقت المتاح للحصة التعليمية. ء. أن أقل العوامل التي تحد من استخدام التقويم التكويني (البنائي) أثناء تتفيذ معلمات الرياضيات عملية التعليم، تتمثل في كثافة محتوى المنهج الدراسي. 
1. تطوير دليل خاص في التقويم التكويني (البنائي)، يشمل الهذف منه، الاستراتيجيات والأدوات، المعايير والمؤشرات، أهيته

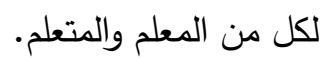

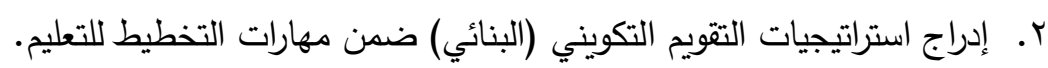

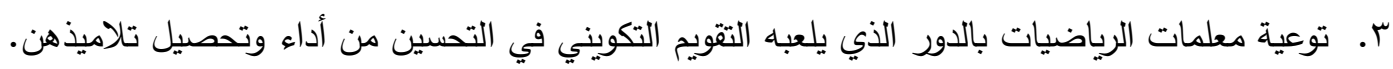

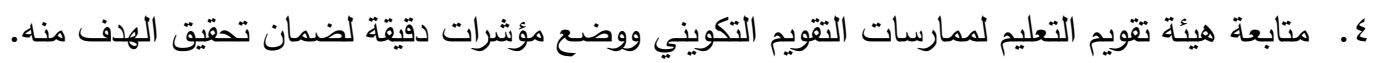
0. زيادة الوقت المتاح للحصة التعليمية لتتاح للمعلمات ممارسة التقويم التكويني (البنائي) أثناء التعليم.

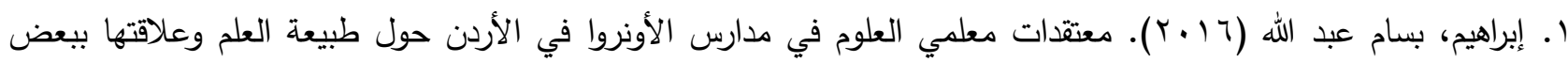

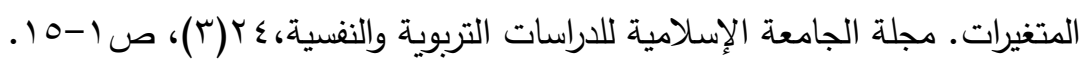

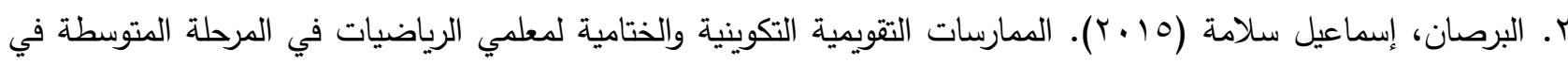

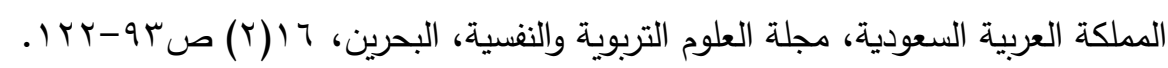

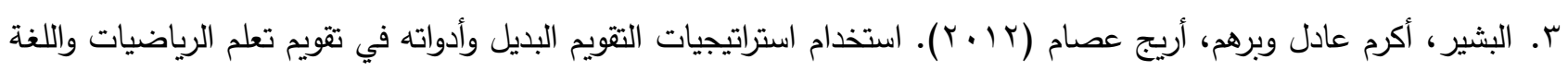

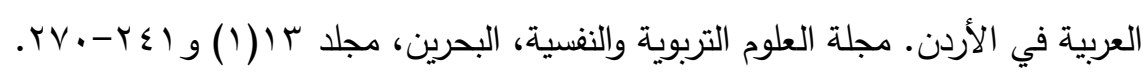

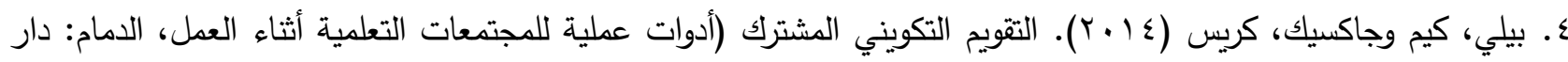

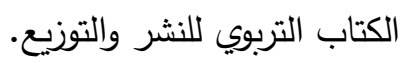
ه. الجعيد، نايف عبد الله (9 . ب). درجة استخدام معلمي اللغة العربية للتقويم التكويني في تدريس مادة القراءة لطلبة المرحلة

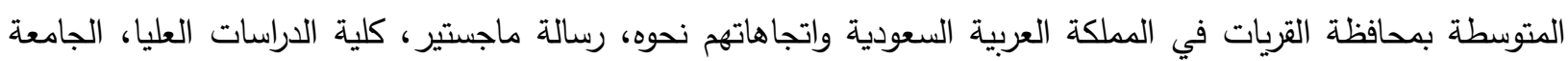
1 الأردنية، الأردن.

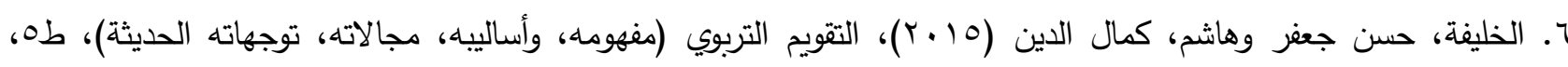

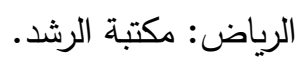

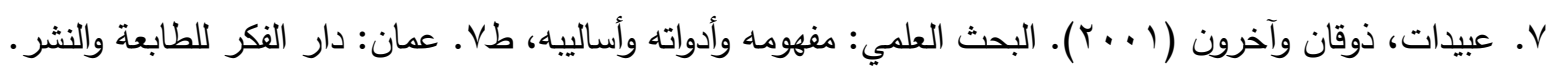

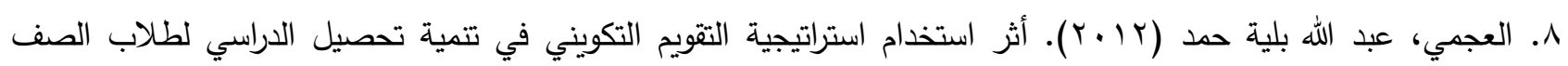

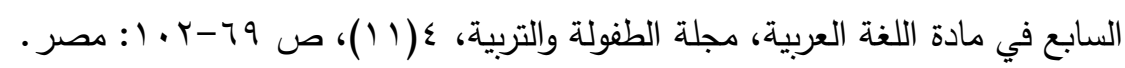

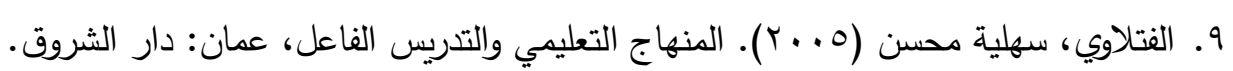

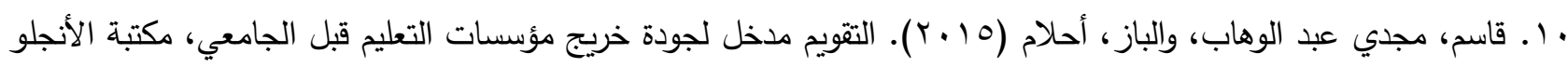

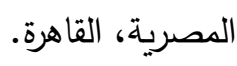

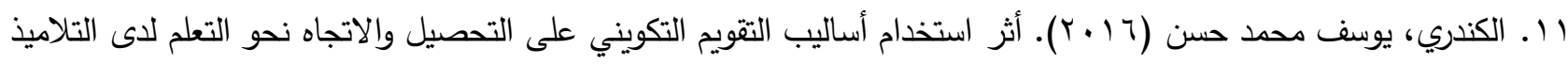

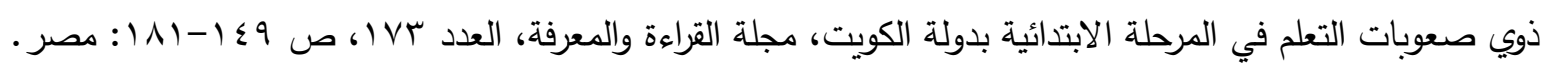

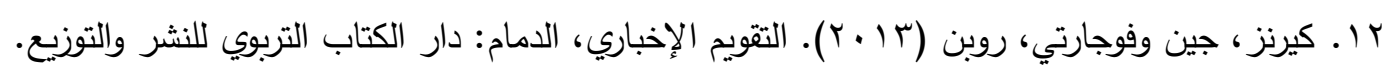




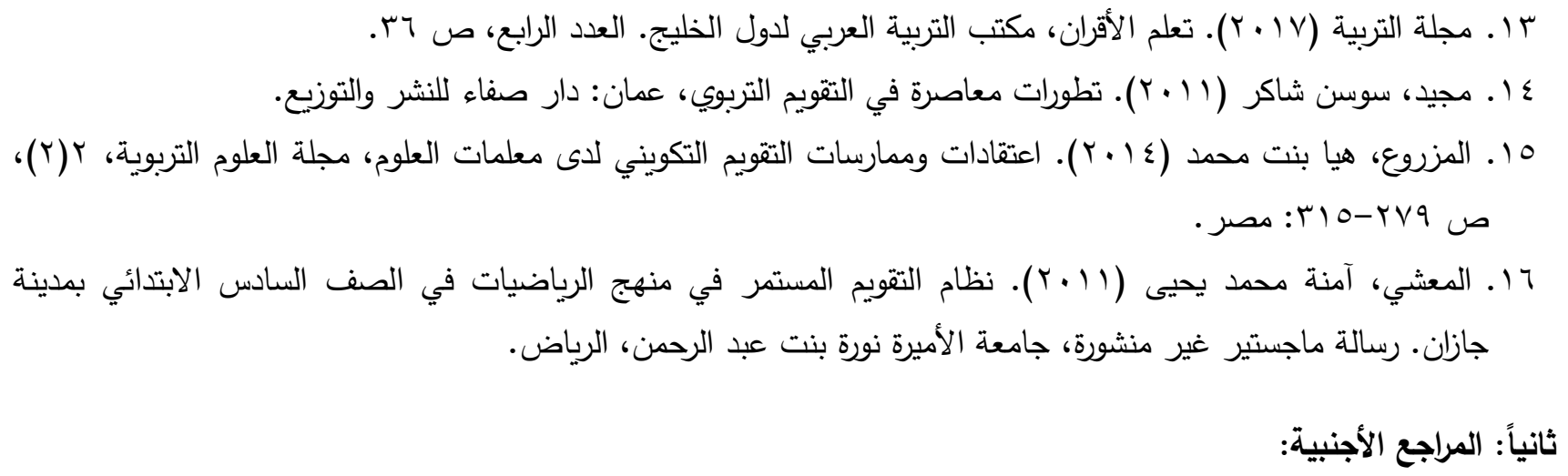

[1] B.G. AustinHurd, (2016). How educators conduct formative assessment with middle school student in order to improve student achievement. Capella University, ProQuest Dissertations Publishing, 2016, 3745101.

[2] O. Belcher , Jr. (2016). Effectiveness of a formative assessment initiative on student achievement in eighth grade math, Mississippi College, ProQuest Dissertations Publishing, 2016, 10128970.

[3] D. DiBiase, (2014). Formative Assessment Professional Development: Impact on Teacher Practice, Johnson \& Wales University, ProQuest Dissertations Publishing, 2014. 3621976.

[4] C.M. Geoghegan, (2014). Understanding teachers' use of formative assessment practices during literacy, university of at Urbana - Champaign, ProQuest Dissertations publishing, 2014. 3646505 . 


\title{
The Beliefs of Mathematics Teachers in Riyadh about
}

\section{Formative Assessment}

\author{
Aishah M. Albalawi \\ Assistant Professor, Department of Curriculum and Teaching Methods- University of Tabuk \\ albalawi.aishah@gmail.com
}

\begin{abstract}
:
This study focuses on exploring the beliefs of mathematical teachers about formative assessment and the most prominent assessment practices that teachers use during education. The sample of this study consisted of (40) mathematics teacher in the northern region schools of Riyadh city. The researcher used the descriptive analytical approach was applied to achieve the objective of this study. The findings showed that there is an analog in the agreement within the sample members on the use of formative assessment, which is informing the students of their academic level, where this statement had the highest arithmetic mean. As for the assessment strategies used during education, the statement: "I care about class observation of my students" obtained the highest arithmetic average. The study also indicated that inefficient class time and the students' concentration in a single classroom limits the teachers' practice of formative assessment strategies. In light of these findings, the study concluded a number of recommendations.
\end{abstract}

Keywords: assessment‘ constructive assessment, feedback, academic achievement. 